\title{
Improving the accuracy of predicting the hazard of the earth's surface failure formation during underground mining of mineral deposits
}

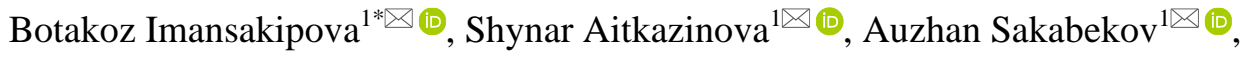 \\ Gulim Shakiyeva $^{1 \otimes(\mathbb{D})}$, Meruyert Imansakipova $^{1 凶}$, Omirzhan Taukebayev ${ }^{1 \otimes(\mathbb{D})}$

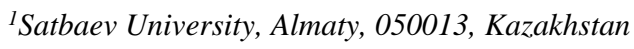 \\ *Corresponding author: e-mail ibb030680@gmail.com, tel.+77778072746
}

\begin{abstract}
Purpose. Development of a new approach to improving the accuracy of predicting situations in which the earth's surface failures occur as a result of undermining a rock mass during the development of mineral deposits.

Methods. The critical situations, including the earth's surface failures, are predicted on the basis of assessing the value of geoenergy and studying its change as large volumes of rock mass are involved in mining. Analytical solutions based on the fundamental laws of physics and mechanics of continuous media are used. The research is performed using methods of cause-and-effect analysis.

Findings. Based on the cause-effect relationship, determined between the change in the value of the mass geoenergy and deformation processes on the daylight surface of the field, an effective method has been developed for ranking it according to the degree of hazard of failure formation with the simultaneous use of two criteria. One of the criteria is determined by the relative change in geoenergy during the system transition from the initial (stable) state to the current one, which becomes unstable under certain conditions. The second criterion is formed on the basis of the change in geoenergy during the transition from the current (possibly unstable) state to the final (stable) state.

Originality. For the first time, when zoning the daylight surface of a field according to the degree of hazard of failure formation, two ranking criteria are used simultaneously, based on the assessment of geoenergy accumulated in a heterogeneous mass, when it is undermined in the conditions of triaxial compression.

Practical implications. The territory ranking method, developed on the basis of the used criteria for hazard of failure formation, allows improving the quality of situational control, predicting risk situations and their development, as well as optimizing the short-term and long-term plans for the development of mining operations.
\end{abstract}

Keywords: failure formation hazard, zone regionalization, prediction, criterion, geoenergy, elastic deformation, ranking

\section{Introduction}

Mining of mineral reserves from the subsoil by the underground method is accompanied by progressive discontinuities, structural changes in the rock mass properties, and various natural and technogenic processes. Against the background of a reactionary change in the stress-strain state (SSS) of the rock mass, existing geomechanical processes are activated and new ones are initiated. In addition, the propagation of tectonic faults is provoked, as well as the failure of rocks in mine workings, which causes a rock mass displacement with a possible outcrop to the earth's surface. Taken together, these processes can lead to negative consequences up to emergency situations [1], [2]. This poses a threat to production, violation of ecological stability and loss of minerals. To ensure the safety of mining operations in these difficult con- ditions, it is necessary to predict risk situations, the reliability and durability of which depend on the effectiveness of monitoring the state and development of deformation processes in the rock mass.

\subsection{Setting of a problem}

Traditional instrumental monitoring of the earth's surface state of the field provides short-term or medium-term predictions exclusively at the stage of stable dynamics of displacement processes due to its limited capabilities. As a rule, it is not possible to identify failure-hazardous areas that are at the stage of being involved in the displacement process, and to determine the moment of their entry into this process. If the duration of such a state of the areas is not determined, due to the complexity of the course of geomechanical processes and the ambiguity of assessing the velocity vector of propagating 
deformation disturbances coming from the depth of the rock mass, this can lead to unforeseen consequences. This may result in an unpredictable emergence of a crisis situation at an unexpected time in an indefinite place on the earth's surface of the field in the form of its subsidence or failure [3].

A typical example of such process development is the situation at the Zhezkazgan copper ore deposit, in particular at the Annensky mine, which is part of it. This is one of the largest copper deposits on the territory of the Republic of Kazakhstan, where a room-and-pillar (panel-and-pillar) mining system is used. Active mining operations have led to the fact that today the volume of accumulated cavities is about 222 million $\mathrm{m}^{3}$ (at least half of them are classified as unstable). On the territory of the mine itself, significant areas fell into the trough formation area, formed as a result of the destruction of room fenders and failures of the partings. The peculiarity of the Annensky mine is the incoherence of the mined-out spaces in plan and along the vertical, the fragmentation of the undermined overlying stratum, the presence of areas of mass and pillars, which were not undermined. At the same time, there are significant balance reserves of ore, containing more than 256 thousand tons of copper, in the shift trough. This trend is of a global nature, characterized by an increase in the intensity of negative manifestations on the earth's surface of mined fields [4], [5]. To predict such situations, a comprehensive analysis of the stress-strain state of the rock mass is required during the formation of a significant volume of mined-out space.

So, at present, at the mining enterprises of China, South Africa, Chile, Ukraine, Russia and Kazakhstan (ShakhtarskaGliboka mine LLC, Mponeng, Western Deep Levels Mine, Witwatersrand, Krasnoyarskaya Mine OJSC, SUEKKuzbass, Kazzinc LLP, etc.), there are failures of the earth's surface that are not predicted according to the regulatory methods [6], [7]. The problem of predicting the hazard of failure formation is very relevant for the Ridder-Sokolny polymetallic deposit, which is located on the outskirts of the city of Ridder (East Kazakhstan region). Almost $70 \%$ of ore is mined by sublevel (and partly horizon) mining systems with caving of the host rocks, $30 \%$ - by the stope system of mining with the backfilling of the mined-out space. The explored ore reserves are sufficient to maintain the current production level for the next 20 years. However, the duration of operation, the scale of work, an increase in the depth of mining the field in the presence of structural disturbances and rock mass-bump hazard, the accumulation of the number of abandoned cavities is a factor leading to hard-to-predict crisis situations. In particular, possible earth's surface failures pose a real threat. In 2014, there was a failure on the territory of a residential area in the city of Ridder, as a result of which a residential building has been damaged. This event has demonstrated a high degree of hazard of the current geomechanical situation. Of particular concern is the possibility of a failure formation under the bed of the Bystrukha River, which flows on the outskirts of the city. If such an event occurs, it can lead to an ecological disaster and flooding of the field.

In such situations, industrial safety, which has been and remains an urgent problem for all mining enterprises, can be solved only in the conditions of ensuring a reliable and longterm prediction of hazardous situations caused by the manifestations of failures. Thus, the development of a scientific and methodological base for identifying such areas is of great scientific and significant practical interest. A qualitative prediction can only be based on the results of the stress-strain state analysis and the development of deformation processes throughout the field.

\subsection{Critical analysis}

Existing prediction methods, which provide detailed information about the forms of genesis and patterns of distribution of disturbances, about changes in the properties and state of the rock mass, make it possible to perform quantitative and qualitative assessments of the conditions for the formation and occurrence of disturbances, the degree of the disturbed state, as well as make an assumption about the directions and intensity of such processes within local areas [8]-[10]. The main disadvantages of these methods are their locality, insufficient reliability and lack of consideration of the time factor.

In Kazakhstan, on the basis of the set cause-effect relationship between the processes in the mass and on the surface, the scientific and methodological base of methods for identifying weakened zones on the earth's surface of ore deposits has been developed [11]-[14].

One of the promising directions for solving this problem is the development of methods for zone regionalization of the field earth's surface according to the degree of problematicity. The methods make it possible to simultaneously identify areas that are at the stage of involvement in the displacement process over the entire field surface. The improvement of such methods is of considerable practical interest. Zone regionalization is made according to the criterion, the basis of which consists of values (parameters) characterizing the state of the mass. The parameters are selected based on the scope of the solved problem and the requirements for accuracy.

Zone regionalization, regardless of the chosen method, is performed according to the following algorithm:

- determining the parameters of the rock mass state which form the basis of the zoning criterion;

- determining the dependence of the criterion on the state parameters;

- determining the numerical values of the state parameters and the zoning criterion for each point of the field earth's surface according to geological, mining, geodetic data and geomechanical documentation;

- plotting the obtained values of the criterion on the field plan and contouring the isolines;

- determining the criterion boundary value which divides the zones according to the hazard degree;

- identification of hazardous zones on the field plan according to the degree of failure formation hazard by the numerical value of the criterion.

The numerical boundary value of the criterion is determined for each field based on a retrospective cause-andeffect analysis of geodynamic events occurring in the rock mass and its structural peculiarities (geological structure, tectonic faults, fracturing, the applied mining system, physical-mechanical properties and the initial stress-strain state of the rock mass). The criterion value is taken to be the same for the entire field territory. Additionally, according to the results of the analysis, the correlation dependence of the maximum permissible subsidence value on the parameters that make up the criterion basis is determined. On the situational map of the field surface, weakened areas, where instrumental monitoring has revealed the presence of a displacement process, are supplemented by problem areas identified by zone regionalization [12]. 
Despite the great potential of the research into deformation processes, the existing methods are limited in accuracy, since they do not reflect the nature of various geomechanical processes occurring in the rock mass. The basis of the criterion for these methods is developed using "dimensional" parameters that determine the rock mass state by such values as the depth and output of the mine working with their summation over the entire field, but does not reflect its properties and stress-strain state. It is also impossible to significantly increase the efficiency of zone regionalization, taking into account the heterogeneity of the rock mass in the direction of improving the criterion [15]-[18]. The most promising methods of zone regionalization are methods using energy parameters that determine the value of geoenergy and its change [19].

Geoenergy, determined by the sum of potential gravitational energy and elastic deformation energy, in terms of its physical orientation, along with the determining the SSS, is the most important tool for increasing the reliability of predicting various geomechanical processes in a rock mass, as well as the general basis for their occurrence and development [20], [21].

Changes in geoenergy are directly caused by cavities of various shapes and sizes created in the rock mass. Therefore, in order to study pre-crisis anomalies in the development of geomechanical processes preceding geodynamic phenomena, much attention has recently been paid to the energy parameters characterizing the rock mass state as an open, dissipative natural and technical system [22]-[24].

In the works [25]-[27] it is shown that in the process of change this system in some rock mass areas reaches a certain critical state, at which it becomes unstable. This happens due to internal and external energy sources, provided that the rate of energy accumulation exceeds its dissipation. Various options for energy schemes and predictions are based on the dependence of the potential energy value on the depth of the rock mass element location and on its redistribution during the development of mining operations under the influence of various geomechanical processes.

This fact was used in the work [18], which demonstrates that the research on geomechanical processes can be greatly simplified by considering the rock mass, in which artificial cavities for various purposes are created, as a single system with a certain supply of potential energy. The latter consists of a gravitational component and elastic deformation energy, which change under the influence of mining operations. In the work [13] it is shown that the definition of geoenergy in the form of the sum of the potential gravitational energy and elastic deformation energy makes it possible to reasonably represent the occurrence and development of various geomechanical processes as a consequence of its change.

\subsection{Identification of an unsolved problem}

In a virgin rock mass, gravitational forces predetermine the formation of a field of initial mechanical stresses under its own weight in an effort of the system to achieve a state of stable equilibrium. However, with the beginning of mining operations, the picture changes dramatically. In the case of the rock mass discontinuity, the dominant role in achieving stability by the system passes to the forces of elastic interaction. Therefore, a significant disadvantage of the above method [11] is the absence in the criterion of an important component of the mass geoenergy - the elastic deformation energy. At the same time, it should be noted that the share of potential energy of elastic deformation increases significantly with the depth of mining the field.

One of the above method main disadvantages [13] is the use of a model of uniaxial elastic compression of the mass under the influence of the weight of overlying rocks to calculate the elastic deformation energy, which does not correspond to reality. As practice shows, as well as in accordance with the A. Geim hypothesis [26], the mass is exposed to triaxial hydrostatic compression. In addition, the use of the difference in geoenergy as a zoning criterion only in the initial (stable) and current (unstable) states of the rock mass reduces the accuracy of the method. This is conditioned by the uncertainty in the distribution of energy between the mass and that part of it that previously filled the mined-out space. This is a direct consequence of the disturbance of system integrity due to non-observance of mass invariance. The process of transition from the initial state to the current one is irreversible and, therefore, a return to the system stability can be achieved only under the influence of external influences.

Further research should be aimed at eliminating of the noted disadvantages. In particular, when developing the criteria, it is necessary to take into account not only the relative change in geoenergy during the transition of the system from the initial state to the current one, but also during the transition from the current state to the final one.

The purpose of this work is to develop improved methods for ranking the territory according to the degree of hazard of failure formation, which is based on the simultaneous use of two complementary criteria that determine the energy state of the system. One of the criteria should determine the system transition from the initial (stable) state to the current one, which may or may not be unstable. The second criterion should determine the possibility of returning the system from the current (possibly unstable) state to a stable state. Thus, the accuracy of identifying the zones in which there is a risk of dynamic development of irreversible deformations with the formation of the earth's surface failures is increased.

It should be noted that one of the most effective methods for maintaining the rock mass stability is the backfilling of the formed cavities. In this case, the system regains stability, in which the "free" energy is transformed into "bound" energy, reducing the intensity of geomechanical processes to the natural level. Otherwise, cavities that are not backfilled and disturb the continuity and stability of the state of the surrounding rock mass continue to cause a reactionary change in its stress-strain state, activate existing and initiate new geomechanical processes until the system reaches a stable state and becomes free from "free" energy. The approach proposed below is based on these principles.

\section{Research methods}

To calculate the criteria, a model is used, according to which the field is divided into mass elements in the form of a square section pillar of a unit area, extending along the z-axis from the lower horizon $(z=0)$ to the daylight surface. To take into account the anisotropy of physical-mechanical properties in accordance with geological-prospecting and geotechnical data, the rock mass is divided into layers, within which the specific gravity (density), Young's modulus and Poisson's ratio can be considered constant (Fig. 1a). 


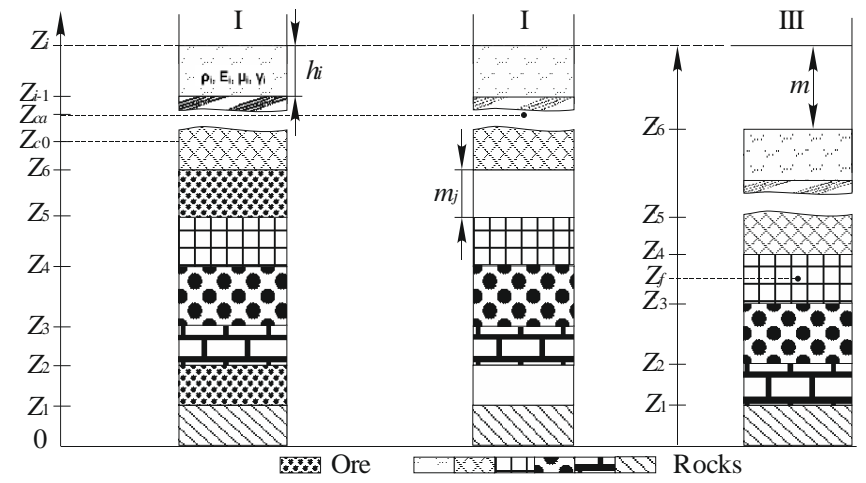

Figure 1. Scheme for calculating the geoenergy of a rock mass: (a) in the initial state; (b) in the current state; (c) in the final state

Each layer separately and pillar as a whole, which are in the gravitational field of the Earth, have potential gravitational energy proportional to its mass (weight). The level at $z=0$ is taken as zero energy level.

In accordance with this, the potential gravitational energy of $\mathrm{i}$-th layer $W_{T_{\mathrm{i}}}$ is equal to:

$W_{T_{i}}=y_{i} h_{i} z_{c i}=g \rho_{i} h_{i} z_{c i}$,

where:

$z_{c i}-$ vertical coordinate of the center of gravity (mass) of the layer;

$g$ - acceleration of gravity.

For an isotropic layer, the vertical coordinate of the mass center and the layer geometric center coincide:

$z_{c i}=\frac{1}{2}\left(z_{i}+z_{i-1}\right)$.

Accordingly, the potential gravitational energy of the entire pillar in the initial state is $W_{T 0}$ :

$W_{T 0}=\sum_{i=1}^{n} W_{T i}=\sum_{i=1}^{n} \gamma_{i} h_{i} z_{c i}=\sum_{i=1}^{n} g \rho_{i} h_{i} z_{c i}$

The same result can be obtained using the vertical component of the mass center of the entire pillar $z_{c}$, which, when determined, is equal to:

$$
z_{c}=\frac{\sum_{i=1}^{n} \rho_{i} h_{i} z_{c i}}{\sum_{i}^{n} \rho_{i} h_{i}}
$$

where:

$z_{i}$ and $z_{i-1}-$ the coordinates of the upper and lower border;

$h_{\mathrm{i}}=z_{i}-z_{i-1}-$ thickness;

$E_{i}-$ Young's modulus;

$\mu_{i}$ - Poisson's ratio;

$\rho_{i}$ - density;

$\gamma_{i}$ - specific gravity of the $i$-th layer;

$m_{j}$ - output of the $j$-th mine working;

$m=\sum m_{j}-$ total output of mine workings.

Each layer is exposed to pressure from the overlying layers, determined by their total weight. As a result of triaxial compression, each layer accumulates the potential energy of elastic deformation with an energy density $\omega_{i}$, which is equal to [28]: $\omega_{i}=\frac{p_{i}^{2}}{2 K_{i}}$

where:

$p_{i}$ - pressure on the $i$-th layer from the side of the overlying layers;

$K_{i}$ - bulk modulus of the layer elasticity:

$P_{i}=\sum_{l=i+1}^{n} \gamma_{l} h_{l}$

$K_{i}=\frac{E_{i}}{3\left(1-2 \mu_{i}\right)}$,

where:

$E_{i}-$ Young's modulus;

$\mu_{i}$ - Poisson's ratio.

Triaxial compression means equality of the initial stresses in the mass:

$\sigma_{x i}=\sigma_{y i}=\sigma_{z i}=\sigma=p_{i}$.

Under one-sided compression, each layer has a potential energy of elastic deformation with a density $\omega_{0 \mathrm{i}}$ :

$\omega_{0 i}=\frac{p_{i}^{2}}{2 E_{i}}$.

The energy capacity of the layer is proportional to the density of its energy. From (5) and (9) it follows that the energy capacity of the rock mass $i$-th layer under triaxial compression can exceed the energy capacity of one-sided compression by more than two times. This ratio is determined by Poisson's ratio and does not depend on Young's modulus:

$\frac{\omega_{i}}{\omega_{0 i}}=3(1-2 \mu)$

From (5), taking into account (6), (7) and (8), the deformation energy of elastic triaxial compression of $i$-th layer $W_{D i}$ is determined as:

$W_{D i}=\omega_{i} V_{i}=\frac{3\left(\sum_{l=i+1}^{n} \gamma_{l} h_{l}\right)^{2}\left(1-2 \mu_{i}\right) h_{i}}{2 E_{i}}$.

where:

$V_{i}=h_{i}-$ a layer volume with a unit cross-sectional area of the pillar.

Accordingly, the total deformation energy of the entire pillar in the initial state $W_{D 0}$ is equal to the sum of energies in its layers:

$W_{D 0}=\sum_{i=1}^{n} W_{D i}=\sum_{i=1}^{n} \frac{3\left(\sum_{l=i+1}^{n} \gamma_{l} h_{l}\right)^{2}\left(1-2 \mu_{i}\right) h_{i}}{2 E_{i}}$,

where:

$n$ - number of layers.

The geoenergy of the entire distinguished rock mass element (pillar) $W_{0}$ in the initial state is determined by the sum of the potential gravitational energy $W_{T 0}$ (3) and elastic deformation energy $W_{D 0}(12)$ : 
$W_{0}=\sum_{i=1}^{n} \gamma_{i} h_{i} z_{c i}+\sum_{i=1}^{n} \frac{3\left(\sum_{l=i+1}^{n} \gamma_{l} h_{l}\right)^{2}\left(1-2 \mu_{i}\right) h_{i}}{2 E_{i}}$.

Mining of minerals is accompanied by the formation of cavities in the rock mass. As a result, instead of some layers in the pillar, mine workings appear (Fig. 1b). This leads to a change in its geoenergy.

The value of geoenergy in the current and intermediate state $W_{P}$ is determined from (13), taking into account the resulting cavities, by a simple restriction within the summation boundaries:

$W_{P}=\sum_{i=1, i \neq j}^{n}\left\{\gamma_{i} h_{i} z_{c i}+\frac{3\left(\sum_{l=i+1}^{n} \gamma_{l} h_{l}\right)^{2}\left(1-2 \mu_{i}\right) h_{i}}{2 E_{i}}\right\}$,

where:

$j$ - the ordinal number of the layer replaced by the minedout space with a vertical dimension $m_{j}\left(m_{j}=h_{i}\right)$.

If the mined-out space covers several layers, then $\mathrm{j}$ is represented by the numbers of the upper and lower layers that form it. An alternative to calculating the energy $W_{P}$ is the direct use of expression (13) when determining the condition $\gamma_{j}=0$ at $i=j$.

Accordingly, the change in energy $\Delta W_{0 P}$ during the rock mass transition from the initial state to the intermediate state is determined by the difference of energies $W_{0}(13)$ and $W_{0}$ (14) or the value of energy that the mined-out layers had before they were extracted:

$\Delta W_{0 P}=\sum_{j=k}^{f} m_{j}\left\{\gamma_{j} z_{c j}+\frac{2 \sum_{i=j}^{m} \gamma_{i} h_{i}}{3 E_{j}\left(1-2 \mu_{j}\right)}\right\}$,

where:

$m_{j}$ - thickness of the $j$-th mined-out layer;

$f$-final number of mine working.

The presence of unabsorbed cavities determines the unstable equilibrium of the system at the current time and motivates its transition to a final state that is stable (Fig. 1c). In this case, each layer is lowered by the value of the total output of the mine workings located under it simultaneously with the vertical coordinate of its center of gravity:

$z_{c i}^{\prime}=z_{c i}-\sum_{j=k}^{i-1} m_{j}$,

where:

$k$ - the number of the first mine working along the vertical, coinciding with the $i$-th layer;

$z_{c i}^{\prime}$-new coordinate of the mass center of the layer.

As a result, the potential energy of the layer in the final state, taking into account (1) and (16), is equal to:

$W_{T i}=\gamma_{i} h_{i}\left(z_{c i}-\sum_{j=k}^{i-1} m_{j}\right)$.
From (17) and (1) it follows, that when the layer is lowered, its gravitational energy decreases by the value of $\Delta W_{T i}$ :

$\Delta W_{T i}=\gamma_{i} h_{i} \sum_{j=k}^{i-1} m_{j}$

In contrast, with a decrease in the layer position, its elastic deformation energy increases under conditions of hydrostatic pressure distribution. This leads to an increase in the density of the elastic deformation energy of the layer $\Delta \omega_{i}$, which is determined from (5) as follows:

$$
\Delta \omega_{i}=\frac{P_{i} \Delta P_{i}}{K_{i}} .
$$

where:

$P_{i}$ - pressure, which is determined by the position of the mass center of the layer:

$P_{i}=P_{0}-\frac{P_{0}}{H} z_{c i}$.

where:

$P_{0}-$ pressure generated by the weight of the entire pillar at zero level, $H=z_{n}$ - its height.

From (20), using (16), the pressure change $\Delta P_{i}$ is:

$\Delta P_{i}=\frac{P_{0}}{H} \sum_{j=k}^{i-1} m_{j}$.

The change in the elastic deformation energy of the $i$-th layer $\Delta W_{D i}$ is determined from (11), taking into account (19), (20), (21):

$\Delta W_{D i}=\Delta \omega_{i} h_{i}=\frac{3\left(\sum_{l=i+1}^{n} \gamma_{l} h_{l}\right)\left(1-2 \mu_{i}\right)}{H \cdot E_{i}} \cdot \sum_{j=k}^{i-1} m_{j}$.

Accordingly, the change in the geoenergy of the entire rock mass pillar $\triangle W_{P K}$ during the transition from the intermediate (current) state to the final state is obtained from (18) and (22):

$$
\Delta W_{P K}=\sum_{i=1, i \neq j}^{m}\left\{\gamma_{i} h_{i}+\frac{3\left(\sum_{l=i+1}^{n} \gamma_{i} h_{i}\right)\left(1-2 \mu_{i}\right)}{H \cdot E_{i}}\right\} \cdot \sum_{j=k}^{i-1} m_{j} .
$$

The relative change in geoenergy $\alpha$ during the rock mass transition from the initial state of the system to the current state, taking into account (13) and (17), is equal to:

$$
\alpha=\frac{\Delta W_{0 P}}{W_{0}}=\frac{\sum_{j=k}^{f} m_{j}\left\{\gamma_{j} z_{c j}+\frac{2 \sum_{i=j}^{m} \gamma_{i} h_{i}}{1-2 \mu_{j}}\right\}}{\sum_{i=1}^{n} \gamma_{i} h_{i} z_{c i}+\sum_{i=1}^{n} \frac{3\left(\sum_{l=i+1}^{n} \gamma_{l} h_{l}\right)^{2}\left(1-2 \mu_{i}\right) h_{i}}{2 E_{i}} .}
$$

The relative change in geoenergy $\beta$ during the transition of the system from the current state to the final state, taking into account (14) and (23), is: 


$$
\beta=\frac{\Delta W_{P K}}{W_{P}}=\frac{\sum_{i=1, i \neq j}^{m}\left\{\gamma_{i} h_{i}+\frac{3\left(\sum_{l=i+1}^{n} \gamma_{i} h_{i}\right)\left(1-2 \mu_{i}\right)}{H \cdot E_{i}}\right\} \cdot \sum_{j=k}^{i-1} m_{j}}{\sum_{i=1, i \neq j}^{n}\left\{\gamma_{i} h_{i} z_{c i}+\frac{3\left(\sum_{l=i+1}^{n} \gamma_{l} h_{l}\right)^{2}\left(1-2 \mu_{i}\right) h_{i}}{2 E_{i}}\right\}} .
$$

The methods for calculating the values of $\alpha$ and $\beta$ predetermines their use as criteria for ranking the earth's surface areas according to the degree of failure formation hazard in accordance with the concept of zone regionalization adopted in the method with the simultaneous use of two criteria.

The zoning method in accordance with the developed criteria is as follows. Over the entire area of the field or its individual sites, for each surface point, the numerical values of the criteria $\alpha$ and $\beta$ are calculated by the Formulas (24) and (25). Current geological sections, mine surveying and geotechnical documentation are used as initial data. The values of $\alpha$ and $\beta$ are indicated on the field plan. By connecting points with the same numerical value, the extrapolation method is used to contour isolines for each criterion separately. Isolines divide the earth's surface into zones, the boundaries of which they are. Thus, a situational map of the site or the field as a whole is created.

Practical testing of the developed method for zone regionalization is conducted at the Ridder-Sokolny polymetallic ore deposit. The deposit has been drilled with 12 vertical shafts to a depth of 460 meters. Mining is conducted at 12 deposits and 18 mining levels (Fig. 2).

Prediction and localization of the hazard of the earth's surface failure formation in the conditions of the RidderSokolny deposit is extremely relevant.

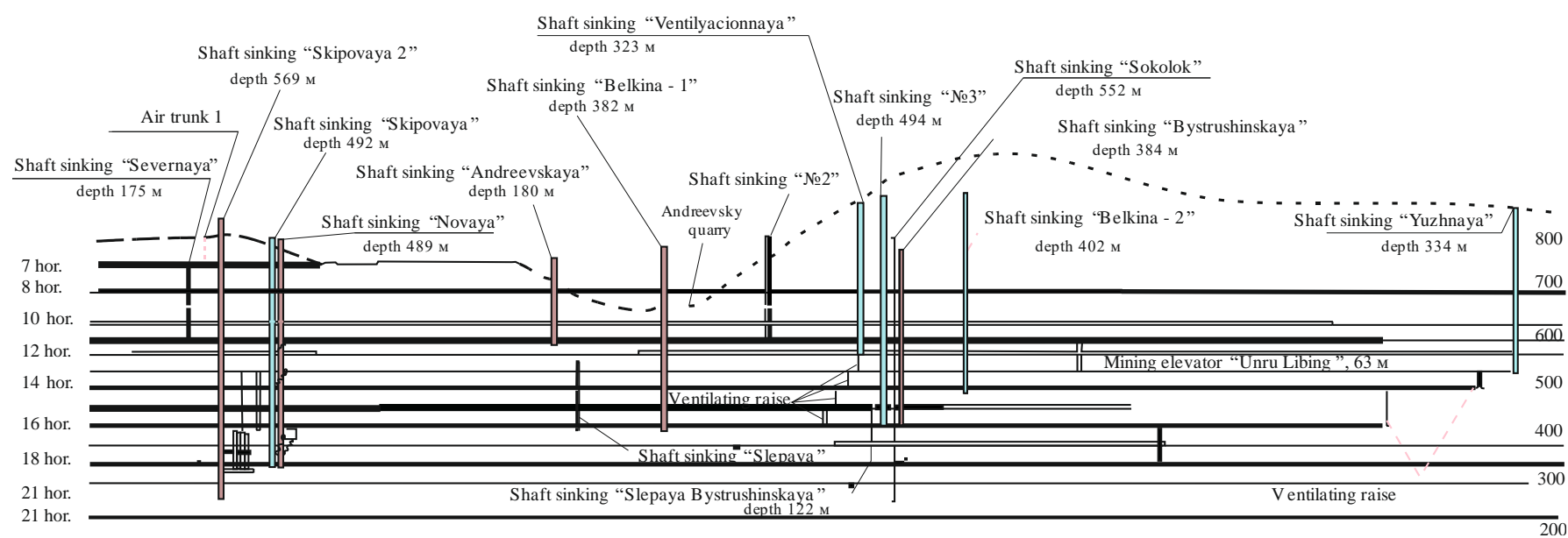

Figure 2. Field opening scheme

To solve this problem, the above method of zone regionalization of the earth's surface has been used to determine the degree of hazard of failure formation with the simultaneous use of two criteria. Based on the data of exploratory wells and the provided technical documentation, the values of the criteria $\alpha$ and $\beta$ have been calculated by Formulas (24) and (25) for each point of the surface. Then the isolines of these values have been contoured, which limit the zones with different degrees of hazard of failure formation.

When classifying the obtained zones by the degree of hazard of failure formation, the most important task is to substantiate the boundary numerical value of each of the criteria, which, in accordance with the zoning algorithm, is set individually for each field. Theoretical calculations can give only an approximate result due to the lack of reliable methods, since many factors must be taken into account in combination with the difficulties in assessing the degree of their influence on various geomechanical processes. As practice shows, the required accuracy and reliability of determining the boundary value of the criterion are achieved by methods combining theoretical and experimental approaches based on the results of geodetic monitoring of the surface, mathematical modeling of the situation development and the cause-andeffect analysis of the crisis events that have occurred.

Under the conditions of the Ridder-Sokolny deposit, eight failures are analyzed, which were formed at different time and on different parts of the surface. The depth of the failures is from 16 to $37 \mathrm{~m}$. For each case, a detailed analysis of the causes of failure formation has been conducted, the parameters included in Expressions (24), (25) have been determined. Thus, for these conditions, the values of the criteria $\alpha$ and $\beta$ have been determined, indicating a certain degree of hazard of failure formation. The number of such degrees in each specific case follows from the purpose and conditions of the set zoning task.

\section{Results and discussion}

For the conditions of the Ridder-Sokolny deposit, five degrees of hazard of failure formation have been substantiated in accordance with the boundary values of each criterion: high degree (both criteria exceed the boundary values), increased according to the $\alpha$ criterion (only the $\alpha$ criterion exceeds the boundary value), increased according to the $\beta$ criterion (only the $\beta$ criterion exceeds the boundary value), medium and low degrees (Table 1). The values of the criteria are calculated by Formulas (24) and (25), but recalculated as a percentage of the geoenergy value in the corresponding state (initial or current). In accordance with the developed classification, the earth's surface zones, limited by the isolines of the values of $\alpha$ and $\beta$, are assigned to one or another degree of hazard. Thus, on the basis of isolines, a situational map of the earth's surface of the Ridder-Sokolny deposit has been compiled (Fig. 3). 
Table 1. Boundary values of the criteria for the specified degrees of failure formation hazard

\begin{tabular}{lcc}
\hline $\begin{array}{c}\text { Degree of failure } \\
\text { formation hazard }\end{array}$ & $\alpha, \%$ & $\beta, \%$ \\
\hline High & $\alpha \geq 13$ & $\beta \geq 19$ \\
\hline Increased by $\alpha$ criterion & $\alpha \geq 13$ & $14 \leq \beta<19$ \\
\hline Increased by $\beta$ criterion & $8 \leq \alpha<13$ & $\beta \geq 19$ \\
\hline Medium & $8 \leq \alpha<13$ & $14 \leq \beta<19$ \\
\hline Low & $\alpha<8$ & $\beta<14$ \\
\hline
\end{tabular}

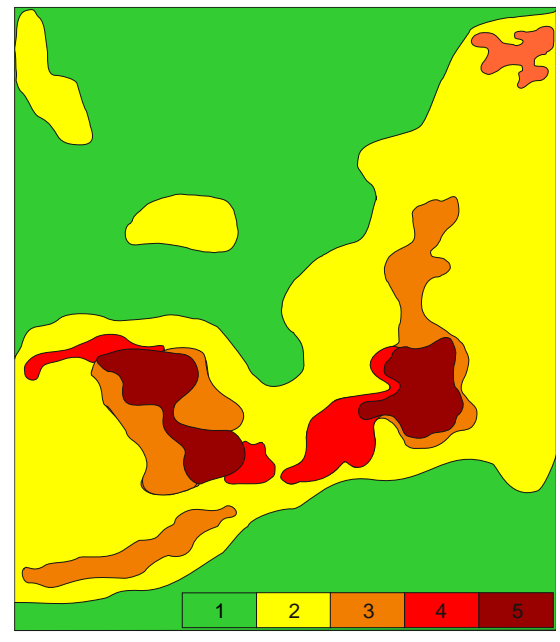

Figure 3. Situational map of the earth's surface area at the Ridder-Sokolny deposit: 1 -low degree; 2 -medium degree; 3 -increased degree (criterion $\alpha$ ); 4 - increased degree (criterion $\beta$ ); 5 - high degree of failure formation hazard

The earth's surface, included in the zone of a high degree of failure formation hazard (dark red), rests on a rock mass containing a network of mine workings, which are located on 11 horizons, with a total volume of cavities over 125 thousand $\mathrm{m}^{3}$. At the same time, only the stopes of the $1^{\text {st }}, 2^{\text {nd }}$ and $11^{\text {th }}$ horizons of block No. 31 , as well as the stopes of the $10^{\text {th }}$ and $11-14^{\text {th }}$ horizons of block No. 2 with a total volume of 27 thousand $\mathrm{m}^{3}$ are backfilled. Analysis of the current situation has shown that in order to reduce the risks and bring the site out of the state of a high degree of failure formation hazard, it is necessary to intensively backfill the remaining cavities. At the same time, the priority of backfilling the stopes, which is also determined by zone regionalization, is of great importance. So, in particular, according to the results of zoning, it has been shown that backfilling of only the stopes of the $2^{\text {nd }}, 5^{\text {th }}$ and $18^{\text {th }}$ horizons of block No. 96 already makes it possible to reduce the degree of failure formation hazard at the site from high to low. Thus, the developed method can be an effective tool for drawing up a plan for backfilling operations.

The results of zone regionalization have been compared with the data obtained by ground geodetic measurements and space radar interferometry, as well as by the results of a retrospective analysis of past events. Verification of the results of the method practical application has shown an increase in the accuracy of zoning by $20-30 \%$ compared to traditional methods, in which only the ratio of the total depth of mine workings $H$ to their total thickness $\mathrm{m}$ is used as a criterion for hazard of failure formation. In addition, the zoning accuracy is increased by $15-20 \%$ in relation to methods that use only the potential gravitational energy [11].
Comparative analysis of the results of zoning according to $\alpha$ and $\beta$ criteria has revealed good convergence at the values of thickness $m<0.05 H$ of mined layers, which corresponds to the zones of medium and low degrees of failure formation hazard (Table 1). At $m>0.05 \mathrm{H}$, the boundaries of the zones of the increased degree of failure formation hazard, determined for each of the criteria separately, may not coincide. This is a consequence of the fact that one of the criteria is based on the parameters characterizing the process of the system's transition to a state of unstable equilibrium, and the second is the exit from it. The combined use of both criteria allows taking into account all possible options for the implementation of geomechanical processes and increasing the reliability of determining the boundaries of zones. In this case, the boundary of the zone of the high degree of failure formation hazard summarizes the zones of the increased degree of hazard, determined separately for each of the criteria. The earth's surface areas that are simultaneously located in zones of an increased degree of failure formation hazard and in accordance with $\alpha$ and $\beta$ criteria are considered the zones of a high degree of failure hazard.

For the conditions of the Ridder-Sokolny deposit, instrumental measurements of the earth's surface maximum subsidence $\eta_{u}$ have been conducted, set in accordance with the calculated values $\alpha$ and $\beta$ of the relative change in geoenergy. The determined dependences have the similar character and, with the reliability of $R^{2}=0.9-0.92$, are described by power functions of the form:

$$
\begin{aligned}
& \eta_{u}=0.39\left(\frac{1}{\alpha}\right)^{2}-2.3 \frac{1}{\alpha}+25.5 ; \\
& \eta_{u}=0.59\left(\frac{1}{\beta}\right)^{2}-3.2 \frac{1}{\beta}+38.2 .
\end{aligned}
$$

The dependency graphs between the maximum subsidence value and the change in geoenergy are shown in Figure 4.

The obtained correlation dependences make it possible to obtain the expected maximum permissible deformations depending on the change in geoenergy, which is determined by the state and properties of the rock mass, the depth and thickness of mining. It is also possible to solve inverse problems, that is, to choose such dimensions of cavities and depths at which the earth's surface deformations do not exceed the maximum permissible for the undermined objects. The relative changes in geoenergy $\alpha$ and $\beta$ in accordance with the concept of the method are the criteria for zoning and, therefore, are known for each point of the mass together with the maximum value of surface subsidence determined from (26) and (27). This makes it possible to assess the degree of failure formation hazard of the site on the basis of comparing the current (measured) value of earth's surface subsidence with the maximum value and thus increase the coefficient of mining minerals in problem areas.

Along with the main task of zoning the earth's surface according to the degree of hazard of failure formation, the proposed method makes it possible to optimize and increase the efficiency of instrumental observations of the earth's surface state. The information content and objectivity of instrumental monitoring depend on the optimal choice of geodetic observation sites for problem areas, which can be identified precisely based on the results of zoning. 
(a)

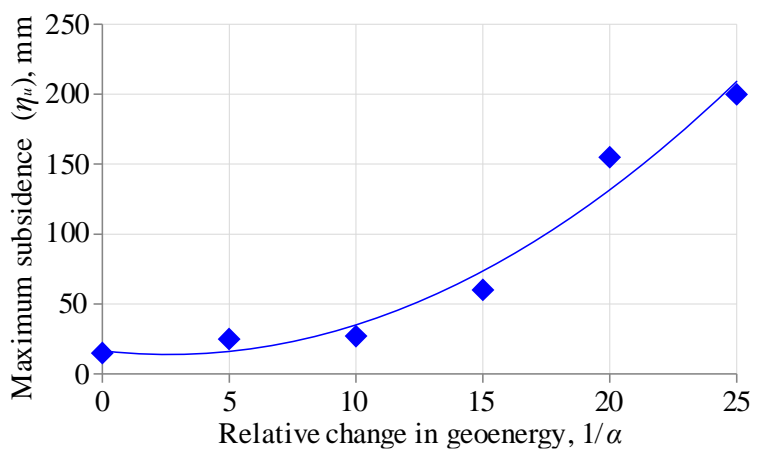

(b)

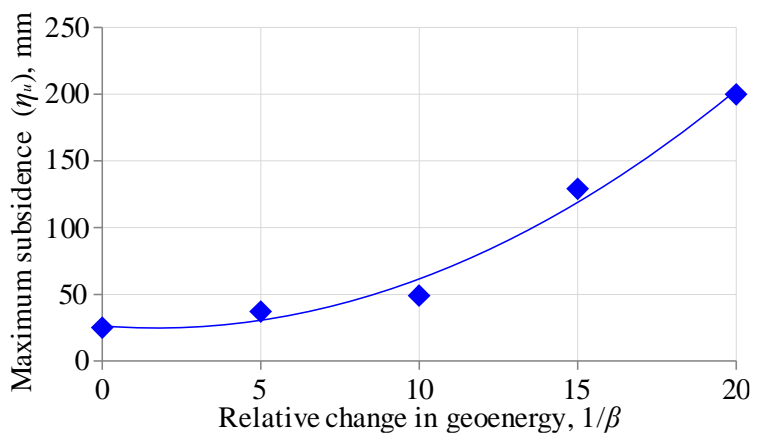

Figure 4. The dependency graphs between the maximum subsidence value and the change in geoenergy: (a) dependence between $\eta_{u}$ and $\alpha$; (b) dependence between $\eta_{u}$ and $\beta$

This approach has been implemented in the conditions of the Ridder-Sokolny deposit when constructing additional profile lines for setting the observation stations and conducting high-precision leveling of the residential area. To monitor the state of the residential area, 6 profile lines were set, located along the streets of Gorky, Khoreva, Borovaya 1, Borovaya 2, Khariuzovskaya and in the area of the concrete pipeline route along the Bystrukha River, which, in accordance with the zoning performed, were in the zone of increased hazard of failure formation. The total length of profile lines with 96 bench marks is $3.3 \mathrm{~km}$ (Fig. 5).

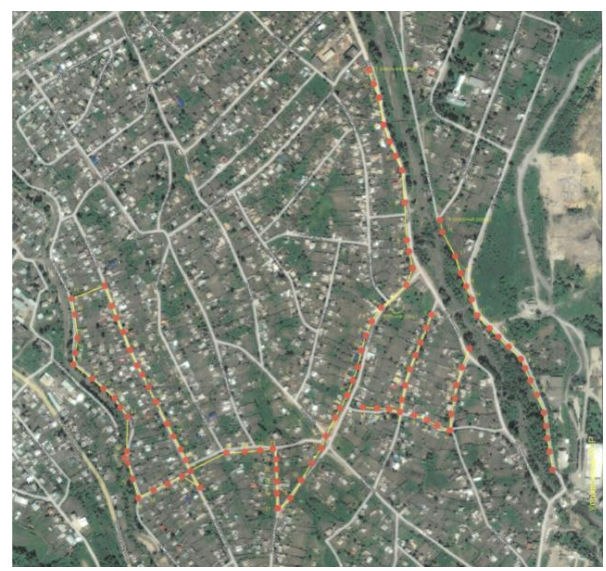

Figure 5. Observation stations located in a residential area

Another direction of optimization of instrumental monitoring is based on the fact that all observation points located on the same isoline, according to the conditions of zoning, are identical from the point of view of the problematic nature of the studied surface area. Moreover, the earth's surface areas located in different parts of the field, but on the same isolines, are also identical in terms of the degree of hazard of failure formation. Therefore, geodetic observations of the earth's surface displacement can be limited to monitoring the state of one arbitrarily selected area. The measurement results can be applied to the corresponding identical areas. This makes it possible to significantly reduce the monitoring time of the entire surface, increase the measurement frequency due to its localization and significantly reduce costs.

Zone regionalization is conducted using a specially developed, problem-oriented geoinformation model of geomechanical risks (GMGR) with a database management system (DBMS). The system is loaded with parameters characterizing the expected spatial-temporal distribution of mine workings, the structure and physical-mechanical properties of the host rock mass, corresponding to each option of mining operations. The DBMS of a model is client-server and objective-relational Postgre SQL with the Post GIS extension, which ensures the storage and processing of large amounts of data obtained as a result of monitoring. In order to operate, the model uses ERDAS IMAGINE software. Based on the results of zoning, for each option of the mining plan, predictive situational maps are created, which make it possible to observe the spatial-temporal development of possible risk situations and assess the degree of their hazard. Based on the cause-and-effect and comparative analysis of situational maps, the optimal mining plan is determined. Mining operations in the hazardous areas are prohibited or substantially limited by safety requirements. Accordingly, when choosing the optimal mining plan, the model is focused on minimizing the loss of balance reserves of minerals, which may not coincide with the minimum value of the area of zones. For this, the DBMS for each site of the field additionally introduces the surface density value of the balance reserves of minerals, which is equal to the ratio of the ore mass to the area under which it occurs.

\section{Conclusions}

Identification of the earth's surface zones that are hazardous from the point of view of the formed failures is possible on the basis of an assessment of the undermined rock mass geoenergy, since the accumulated potential energy is directly related to the volume of cavities formed as a result of mining operations, as well as to the elastic properties of rocks. This makes it possible to develop a criterion for the rock mass transition to an unstable state, and the parameters of the criterion are easily determined for the mined area.

The concept of assessing the geoenergy of the mass as an indicator of critical states has been developed in this work with the simultaneous use of two criteria of failure formation. One of them is determined by the relative change in geoenergy during the transition from the initial (stable) state of the energy system to the current state, which, with an unfavorable combination of factors, can be unstable and, therefore, hazardous from the point of view of failure formation. The second criterion determines the possibility of returning the system from the current (possibly unstable) state to a stable one. The simultaneous use of two criteria for hazard of failure formation makes it possible to increase the reliability of identifying hazardous zones over the field area, which is confirmed by geodetic observations. 
In terms of its capabilities, the proposed method is an effective tool for increasing the reliability of predicting the failure-hazardous situations, as well as correcting the mining development plans in order to minimize risks. This allows avoiding uncertainty and unpredictability in the manifestation of failure-hazardous situations by constantly monitoring their development and making decisions to eliminate them.

\section{Acknowledgements}

This paper has been written based on the research and development results on the topics: "Development of a highly efficient system for diagnostics of the stress-strain state of a rock mass and a spatial-temporal analysis of deformation process development throughout the field" No. 2021/AP09261035 and "Development of innovative methods for predicting and assessing the rock mass state to prevent technogenic emergencies" No. 2020/AP08053410.

\section{References}

[1] Zheng, L., Zhu, L., Wang, W., Guo, L., \& Chen, B. (2020). Land subsidence related to coal mining in China revealed by L-band in SAR analysis. International Journal of Environmental Research and Public Health, 17(4), 1170. https://doi.org/10.3390/ijerph17041170

[2] Ryl'nikova, M.V., Yun, A.B., \& Terent'yeva, I.V. (2015). Perspektivy i strategiya osvoeniya Zhezkazganskogo mestorozhdeniya. Gornyy Zhurnal, (5), 44-49.

[3] Nurpeissova, M., Bekbassarov, S., Bek, A., Kyrgizbaeva, G., Turisbekov, S., \& Ormanbekova, A. (2020). The geodetic monitoring of the engineering structures stability conditions. Journal of Engineering and Applied $\quad$ Sciences, $\quad$ 12(11), https://doi.org/10.3923/jeasci.2017.9151.9163

[4] Zhiqiang, W., Jianyong, Q., \& Zehua, S. (2021). Environmental impact of the technology for the development of high-power coal seams with a step-by-step arrangement of drifts. Mining Informational and Analytical Bulletin, 2(1), 30-39. https://doi.org/10.25018/0236-1493-2021-21$\underline{\text { 0-30-39 }}$

[5] Prokopov, A., Shuiskii, A., Shcherban, E., \& Zhur, V. (2020) Prediction of deformations in the subsiding soils of Eastern Donbass' undermined areas. E3S Web of Conferences, (164), 07002 https://doi.org/10.1051/e3sconf/202016407002

[6] Panzhin, A.A., Sashurin, A.D., Panzhina, N.A., \& Mazurov, B.T. (2016). Geodezicheskoe obespechenie geodinamicheskogo monitoringa ob'ektov nedropol'zovaniya. Vestnik SGUGiT, 4(36), 26-39.

[7] Li, X., Wang, D., Li, C., \& Liu, Z. (2019). Numerical simulation of surface subsidence and backfill material movement induced by underground mining. Advances in Civil Engineering, (2019), 2724370. https://doi.org/10.1155/2019/2724370

[8] Shpakov, P.S., Dolgonosov, V.N., Nagibin, A.A., \& Kaygorodova, E.V. (2015). Chislennoe modelirovanie napryazhenno-deformirovannogo sostoyaniya massiva v okrestnosti ochistnogo prostranstva v programme "Phase 2". Gornyy Informatsionno-Analiticheskiy Byulleten', (9), 59-66.

[9] Suchowerska Iwanec, A.M., Carter, J.P., \& Hambleton, J.P. (2016). Geomechanics of subsidence above single and multi-seam coal mining. Journal of Rock Mechanics and Geotechnical Engineering, 8(3), 304313. https://doi.org/10.1016/j.jrmge.2015.11.007

[10] Kutepov, Yu.Yu., \& Borger, E.B. (2017). Chislennoe modelirovanie protsessa sdvizheniya porodnykh massivov primenitel'no k gornogeologicheskim usloviyam shakhty imeni Rubana v Kuzbasse. Gornyy Informatsionno-Analiticheskiy Byulleten', (5), 66-75.
[11] Imansakipova, B.B., Sdvyzhkova, O.O., Aitkazinova, Sh.K., Isabayev, Z., \& Shakieva, G. (2018). The combined method for assessing risk factors in underground construction. Naukovyi Visnyk Natsionalnoho Hirnychoho Universytetu, (3), 53-58. https://doi.org/10.33271/nvngu/2020-3/053

[12] Kozhaev, Z.T., Mukhamedgalieva, M.A., Imansakipova, B.B., \& Mustafin, M.G. (2017). Geoinformation system for geomechanical monitoring of ore deposits using spaceborn radar interferometry methods. Gornyi Zhurnal, 39-44. https://doi.org/10.17580/gzh.2017.02.07

[13] Baygurin, Zh.D., Kozhaev, Zh.T., \& Imansakipova, B.B. (2018) The situation forecast for the extraction of ore reserves in the weakened sections of the deposit. Sofia, Bulgaria, $355 \mathrm{p}$.

[14] Spitsyn, A.A., Imansakipova, B.B., Chernov, A.V., \& Kidirbaev, B.I. (2019). Razvite nauchno-metodicheskoy bazy vyyavleniya oslablennykh zon na zemnoy poverkhnosti rudnykh mestorozhdeniy. Gornyy Zhurnal Rossii, (9), 63-66.

[15] Zuev, P., \& Vedernikov, A. (2020) Zoning of town on undermined territory using GIS software. E3S Web of Conferences, (177), 02007. https://doi.org/10.1051/e3sconf/202017702007

[16] Sdvyzhkova, O., Babets, D., Moldabayev, S., Rysbekov, K., \& Sarybayev, M. (2020). Mathematical modeling a stochastic variation of rock properties at an excavation design. International Multidisciplinary Scientific GeoConference Surveying Geology and Mining Ecology Management, 165-172. https://doi.org/10.5593/sgem2020/1.2/s03.021

[17] Babets, D. (2018). Rock mass strength estimation using structural factor based on statistical strength theory. Solid State Phenomena, (277), 111-122. https://doi.org/10.4028/www.scientific.net/SSP.277.111

[18] Sdvizhkova, Ye.A., Babets, D.V., \& Smirnov, A.V. (2014). Support loading of assembly chamber in terms of Western Donbas plough longwall. Naukovyi Visnyk Natsionalnoho Hirnychoho Universytetu, (5), 26-32.

[19] Imansakipova, B.B., Baygurin, Zh., Altayeva, A.A., Kanapiyanova, D.G., \& Myngzhasarov, B. (2020). Development of an effective method for zoning the earth's surface in heterogeneity of the rock mass. Naukovyi Visnyk Natsionalnoho Hirnychoho Universytetu, (4), 5-10. https://doi.org/10.33271/nvngu/2020-4/005

[20] Shemyakin, E.I. (2006). Mekhanika gornogo massiva. Gornyy Informatsionno-Analiticheskiy Byulleten', (3), 5-17.

[21] Feit, G.N., Malinnikova, O.N., Zykov, V.S., \& Rudakov, V.A. (2002). Prediction of rockburst and sudden outburst hazard on the basis of estimate of rock-mass energy. Journal of Mining Science, 38(1), 61-63. https://doi.org/10.1023/A:1020296803432

[22] Fedorov, E., Kassymkanova, K.-K., Jangulova, G., \& Miletenko, N. (2020). The influence of extensive caving zones on the state and behavior of the surface as a result of underground mining works. E3S Web of Conferences, 192, 03009. https://doi.org/10.1051/e3sconf/202019203009

[23] Zhang, Z., Luo, C., Zhang, H., \& Gong, R. (2020). Rockburst identification method based on energy storage limit of surrounding rock. Energies, 13(2), 343. https://doi.org/10.3390/en13020343

[24] Sidorov, D.V., \& Ponomarenko, T.V. (2020). Estimation methodology for geodynamic behavior of nature-and-technology systems in implementation of mineral mining projects. Gornyi Zhurnal, (1), 49-52. https://doi.org/10.17580/gzh.2020.01.09

[25] Chang, Y., Chang, L., \& Ren, F. (2021). Energy catastrophe of jointed rock slope considering spatiotemporal variability of strength. Geotechnical and Geological Engineering, 39(3), 547-2564. https://doi.org/10.1007/s10706-020-01645-3

[26] Kojić, I., Bechtel, A., Aleksić, N., Životić, D., Trifunović, S., Gajica, G., \& Stojanović, K. (2021). Study of the synergetic effect of copyrolysis of lignite and high-density polyethylene aiming to improve utilization of low-rank coal. Polymers, 13(5), 759. https://doi.org/10.3390/polym13050759

[27] Salmi, E.F., \& Sellers, E.J. (2021). A review of the methods to incorporate the geological and geotechnical characteristics of rock masses in blastability assessments for selective blast design. Engineering Geology, (281), 105970. https://doi.org/10.1016/j.enggeo.2020.105970

[28] Shemyakin, E.I. (2006). Mekhanika gornogo massiva. Gornyy Informatsionno-Analiticheskiy Byulleten', (3), 5-17.

\section{Підвищення точності прогнозу провалонебезпеки земної поверхні при підземній розробці корисних копалин}

\section{Б. Імансакіпова, Ш. Айтказінова, А. Сакабеков, Г. Шакієва, М. Імансакіпова, О. Таукебаєв}

Мета. Розробка нового підходу до підвищення точності прогнозу ситуацій, за яких внаслідок підробки породного масиву при вийманні корисних копалин виникають провали земної поверхні.

Методика. Прогноз критичних ситуацій, у тому числі провалів земної поверхні, виконується на основі оцінки величини геоенергії та дослідження іiї зміни у міру залучення у відпрацювання великих обсягів гірничої маси. Використані аналітичні рішення, що базуються на фундаментальних законах фізики та механіки суцільних середовищ. Дослідження виконувались із використанням методів причинно-наслідкового аналізу. 
Результати. На основі встановлення причинно-наслідкового зв'язку між зміною величини геоенергії масиву та деформаційними процесами на денній поверхні родовища розроблено ефективний метод ії ранжування за ступенем провалонебезпеки одночасно за двома критеріями. Один із критеріїв визначається відносною зміною геоенергії при переході 3 початкового (стійкого) стану системи в поточний, який у певних умовах стає нестійким. Другий критерій формується на основі зміни геоенергії при переході 3 поточного (можливо нестійкого) стану в кінцевий (стійкий).

Наукова новизна. Вперше при районуванні денної поверхні родовища за рівнем провалонебезпеки використовуються одночасно два критерії ранжирування, засновані на оцінці геоенергії, що накопичується в неоднорідному масиві в міру його підробки в умовах всебічного стиску.

Практична значимість. Метод ранжування територій, розроблений на основі використання критеріїв провалонебезпеки, дозволяє підвищити якість ситуаційного контролю, прогнозу ризикових ситуацій та їх розвитку, оптимізувати короткостроковий та довгостроковий плани розвитку гірничих робіт.

Ключові слова: провалонебезпека, зонне районування, прогноз, критерій, геоенергія, пружна деформачія, ранжування

\section{Повышение точности прогноза провалоопасности земной поверхности при подземной разработке полезных ископаемых}

\section{Б. Имансакипова, Ш. Айтказинова, А. Сакабеков, Г. Шакиева, М. Имансакипова, О. Таукебаев}

Цель. Разработка нового подхода к повышению точности прогноза ситуаций, при которых вследствие подработки породного массива при выемке полезного ископаемого возникают провалы земной поверхности.

Методика. Прогноз критических ситуаций, в том числе провалов земной поверхности, выполняется на основе оценки величины геоэнергии и исследования ее изменения по мере вовлечения в отработку больших объемов горной массы. Использованы аналитические решения, базирующиеся на фундаментальных законах физики и механики сплошных сред. Исследования выполнялись с использованием методов причинно-следственного анализа.

Результаты. На основе установления причинно-следственной связи между изменением величины геоэнергии массива и деформационными процессами на дневной поверхности месторождения разработан эффективный метод ее ранжирования по степени провалоопасности одновременно по двум критериям. Один из критериев определяется относительным изменением геоэнергии при переходе из начального (устойчивого) состояния системы в текущее, которое в определенных условиях становится неустойчивым. Второй критерий формируется на основе изменения геоэнергии при переходе из текущего (возможно неустойчивого) состояния в конечное (устойчивое).

Научная новизна. Впервые при районировании дневной поверхности месторождения по степени провалоопасности используются одновременно два критерия ранжирования, основанные на оценке геоэнергии, накапливаемой в неоднородном массиве по мере его подработки в условиях всестороннего сжатия.

Практическая значимость. Метод ранжирования территорий, разработанный на основе использования критериев провалоопасности, позволяет повысить качество ситуационного контроля, прогноза рисковых ситуаций и их развития, оптимизировать краткосрочный и долгосрочный планы развития горных работ.

Ключевые слова: провалоопасность, зонное районирование, прогноз, критерий, геоэнергия, упругая деформаџия, ранжирование 